Journal of Humanities and Social Sciences Studies (JHSSS)

ISSN: 2663-7197

DOI: 10.32996/jhsss

Journal homepage: https://al-kindipublisher.com/index.php/jhsss

\title{
The Governance of Sustainable Development According to Imam Ali's Letter 53 and the UN Agenda 2030: A Comparative Study of the Two Charters \\ IFISS SAIDA ${ }^{* 1} \&$ MSSASSI SAID ${ }^{2}$ \\ ${ }^{1}$ PhD Student: The National School of Business and Management, Abdelmalek University Essaâdi, Tangier, Morocco \\ 2Professor: The National School of Business and Management, Abdelmalek University Essaâdi, Tangier, Morocco \\ Corresponding Author: IFISS SAIDA, E-mail: sifiss@uae.ac.ma
}

\section{ARTICLE INFORMATION}

Received: October 05, 2020

Accepted: November 15, 2020

Volume: 2

Issue: 6

DOI: 10.32996/jhsss.2020.2.6.13

\section{KEYWORDS}

Sustainable Development, Governance, Imam Ali, Letter 53, Agenda 2030

\section{ABSTRACT}

This research is a comparative study between the famous Letter 53 of Imam Ali Ibn Abi Taleb and the UN Agenda 2030. With a textual analysis of the 117 passages of the fourth Caliph's epistle, we study sustainable development goals (SDGs) stated by Agenda 2030 in Letter 53. Besides, we analyze the governance of sustainable development, according to Imam Ali's economic vision. In the light of this comparative study, it has been observed that SDGs $1,2,3,4,5,6,7,8,10$, 13, 14, 15, 16, 17 of Agenda 2030 are the most expressed in the said Letter. Finally, we conclude our analysis with a comparative table showing a substantial similarity between the two charters' vision. Nevertheless, some differences appear in specific themes' objectives and a growing distinction between the SDGs and those grouped under Innovation and Technological Improvement.

\section{Introduction}

Since the 1970s, the germ of civilization has been threatening. The failure of growth models observed in many countries has led Humanity to its loss (Châtaigner \& Caron, 2017). Moreover, the 2015 World Bank report attests that billions of people live in poverty, and the gap between rich and poor is widening.

In all areas, the balance sheet is alarming, and the current crises are not only orchestrated by economic, financial, or social factors. Ecological factors should be of more significant concern. Economic imbalances can be corrected, financial systems strengthened, social conditions improved, but can the planet's carrying capacity provide ecological services to the entire human population?

At this time, planet Earth is going through critical and complex challenges for sustainable development. The progress made by humankind has provoked internal conflicts and civil wars often accompanied by humanitarian crises caused by the forced displacement of populations, followed by famines or epidemics, leading to very high death rates.

The main threats facing humanity can be added to climate change or the erosion of biodiversity, the depletion of natural resources, pollution, soil degradation, water scarcity, too high temperatures, and food insecurity. Without over-dramatizing, the challenges of Sustainable Development are far from being won. As Gilpin (2016) points out, the survival of many societies and ecosystems on the planet is in danger.

In the face of this new international disorder, the world is anxious to support a new form of participatory democracy for sustainable development (SD) under the standard label of "good environmental governance." Governance must be treated as a management tool to design or operationalize SD principles (Hyden, 2001). Since then, we have watched with great attention a series of initiatives that prioritize SD. Of course, this is the Agenda 2030 for Sustainable Development adopted by the United Nations on September 25, 2015, announced as a global collective project.

Earlier, the UN, in its 2002 annual report on human development, had called on almost all countries to consider Imam Ali's recommendations in their economic, political, legal, social, and educational programs (PNUD, 2002). More than a thousand

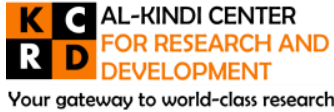

Published by Al-Kindi Center for Research and Development. Copyright (c) the author(s). This is an open access article under CC BY license (https://creativecommons.org/licenses/by/4.0/) 
years ago, Imam Ali wrote a letter known in the literature as Letter 532 , addressed to Malik Al Ashtar upon his appointment as governor of Egypt when unrest broke out under his predecessor's rule, Mohammed ibn Abi Bakr. Six passages from this Letter can be found in the report of the United Nations Development Programme. Former UN Secretary-General Kofi Annan says that it was "the largest letter on government ever written by a human being" (Nakshawani, 2012).

Moreover, the examination of this fair charter shows that its passages consider current development issues and the urgency to improve living conditions and the future of Humanity. In response to these challenges, it provides an essential mechanism of good governance for sustainable development.

Carried by a universal vocation, just like the Agenda 2030 for sustainable development, Letter 53 is a project for the profound transformation of human activities to find the path to sustainable development. This observation provokes a comparison between these two writings and deserves a deep reflection to provide an enlightening analysis of Imam Ali's vision - and even Policy - of sustainable development. Such is the objective of this research.

This study presents several originalities. When research on governance for SD is multiplying, few works have been identified that deal with Imam Ali's reflections on development actions and trace the contours of 7th-century governance that organizes the life of the social body and its environment up to the present day. Moreover, most academic research on Letter 53 is limited to the spiritual aspect of the human being. This head of State's work is rarely explained in its economic, social, or environmental dimension.

The importance given to this work leads us to ask ourselves a few questions: do the visions of environmental governance published in these two charters of Imam Ali and the United Nations present notable similarities? If so, did Imam Ali's Letter to Malik inspire Agenda 2030 to draw up his sustainable development project? Can the Letter be considered as one of the first documents on good governance for SD? Can this testament's recommendations serve as a mirror for the questions that have emerged in recent years around SD?

Moreover, the article includes four sections in which are presented a review of the literature (1), the critical sustainable development themes of Agenda 2030 (2), the methodological approach used (3), and the results of the analysis, which take stock of the comparison between these two charters (4).

\section{Governance in the context of sustainable development: what does the literature say?}

Governance and sustainable development (now SD) are terms with a similar history. They were explored and adopted in the late 1980s, with common characteristics. Issues of governance and sustainability are critical in the 21st century. They are fundamentally about the relationships that define the distribution of resources on our planet (Lennan \& Ngoma, 2004). More specifically, they are about the consequences of choices that are made in the name of SD.

As a result of multiple requirements, SD is an internationally recognized goal that public organizations should pursue (Meadowcroft, 2007). Indeed, nations face development challenges and fundamental crises related to famine, poverty, inequality, and human survival. In these circumstances, good governance must be treated as a management tool to achieve SD (Hyden, 2001). In this spirit, the introduction to the "Plan of Implementation" adopted at the 2002 World Summit on Sustainable Development stated: "Good governance in each country and at the international level is essential for sustainable development."

Governance scholars who share this view consider that neither of these formulations goes very far (Kemp et al., 2005; Meadowcroft, 2007). The first is simply an assertion that "good governance" encompasses all internationally legitimized norms, while the second is likely to be true for any meaningful social purpose. Moreover, they suggest that concern for SD is part of what it means to practice good governance that without it, we will not be able to achieve desirable social goals.

Since it was brought to the attention of the World Commission on Environment and Development (WCED) in 1987, the concept of SD has incorporated constraints related to environmental protection, promotion of well-being, especially the urgent needs of the poor, concern for the well-being of future generations, public participation in decision-making on environment and development. SD is not only an economic and social concept., but its dimension should be by far the most worrying is environmental (ONU, 2017). This environmentally friendly SD, which ensures socially inclusive economic growth,

\footnotetext{
${ }^{2}$ This letter can be found in Ali ibn Abî Tâlib , (1989). The way of eloquence. Translation into French of the Arabic text Nahj al-Balâghah by a group of Muslim
} specialists. Reviewed and corrected by Sayyid Attia Abul Naga. 
requires a change in the game (Hyden, 2001) and a shift in power relations. To achieve this, it will be necessary to rethink public organizations' governance to achieve sustainability, prosperity, equity, and peace.

SD as an approach to poverty reduction is not a spontaneous social product: it requires an understanding of ministries and public agencies' role in establishing quality governance. However, the public organization is of fundamental importance because it is closest to the citizens, to whom it provides essential services. In other words, each organization is a bearer of sustainability that contributes to the operationalization of SD objectives (waste recycling; transition to sustainable lifestyles and changes in the behavior of producers and/or consumers; sustainable mobility). It must consistently integrate socioenvironmental components into its strategic roadmaps. In this respect, its SD governance is closely linked to understanding economic, social, political, environmental, and technological development (Hyden, 2001; Lennan \& Ngoma, 2004).

The transition towards more sustainable growth requires us to question economic and social models that satisfy Humanity's growing needs without putting negative pressure on the environment and the quality of life (Heal \& Le Kama, 2011). The main challenge for countries is to develop inclusive practices in a context where economic and social resources are limited. They are called upon to maximize resources and work within the parameters of effectiveness and efficiency. When resources are limited, SDGs generate development models based on the compatibility of economic prosperity and respect for people and territories. More concretely, this necessarily involves strengthening activities that are in line with the social objectives sought. The most convincing example of this is promoting the green business sector (renewable energy, organic agriculture, etc.). In addition to this, development strategies and programs that consider food, education, energy, social protection, housing, infrastructure, etc. are needed.

In response to these needs, governance for sustainable development requires a consultative approach with private stakeholders. Public-private partnerships (now PPPs) are mentioned as a potential means of achieving sustainability (Hueskes et al., 2017; Marx, 2019). This public-private arrangement in the provision of public services attempts to combine the best of both worlds: the private sector with its resources, knowledge, technology, management skills, and implementation and enforcement capabilities (e.g., coverage of citizens in rural and remote areas), and the public sector with its regulatory actions and protection of the public interest.

Partnership in various forms has begun its journey worldwide, in both developed and developing countries (Paoletto, 2000). These forms, which are categorized according to the extent of participation and the degree of risk allocation between the two sectors, range from a concession granted by a government-owned entity, outsourcing the delivery of public services to private entities, to outright privatization, where the government transfers all responsibilities, risks, and rewards for service delivery to the private sector. It should be noted, however, that the latter, in many cases, is motivated by profit and may then not place sufficient emphasis on quality or safety for the general public (Ara \& Khan, 2016).

In addition to this partnership, there are other essential ingredients for implementing a commitment to SD. Accountability, disclosure of information, public debate, collaboration, consensus building. Of course, this does not mean that SD governance is the realignment of the relationship between the State and citizens. The objective is to responsibly involve the actors or populations concerned by sustainable development policies and their action plans and reach the right decisions to the majority, as far possible, and that converge towards the common good.

In this vein, the literature on the search for sustainability has marked the evolution of modes of governance that have reshaped the landscape of relations between citizens and public organization, from the application of rules by the Administration to exercise its power over citizens (bureaucratic paradigm), through the provision of public services by the Administration to meet the needs of citizens (consumerist paradigm), to the sharing of responsibilities between the Administration and citizens (participatory paradigm).

In his 2018 review of the literature on public governance for SD, Janowski et al. spoke of the birth of a new paradigm of "platform governance," the successor to the bureaucratic, consumerist and participatory governance paradigms. They say that platform governance "is a recent governance model that aims to improve citizens' living conditions and other SD actors." This innovative form of governance reconceptualizes the relationship between three primary entities. First, the Administration represents all state actors with the mandate to direct, coordinate, and regulate development processes. The second, the Citizens, includes businesses and other non-state actors and all other persons who legitimize the Administration to act on their behalf and participate directly in development processes. The third, the Policy, represents the systems of rules 
and regulations that the Administration applies to submit its decisions to citizens' scrutiny (disclosure), who commit to sharing information, opinions, knowledge, and experiences (collaborate). Through this empowering relationship, citizens can learn, monitor policy performance, and benefit from development results. More generally, platform governance enables the co-creation of public value between citizens and the Administration (Linders, 2012) to pursue a range of collective objectives such as fighting crime, discrimination, and corruption, monitoring living conditions, managing social welfare, identifying public health risks, planning public spaces, etc.

Public governance for sustainability also needs to be more anticipatory, long-term oriented, and concerned with learning to innovate and adapt. Technological innovations alone promise only some of the necessary improvements towards sustainability, but sustainability requires systemic innovation (Kemp et al., 2005). Systemic innovation is a fundamental change in goods provision systems, associated with new knowledge, different rules and roles, and a new logic of relevance. Chain mobility is an example of systemic innovation with environmental benefits. In this mobility vision, users use different modes of transport (collective and individual) based on mobility agencies' information that offers travel plans and reservation possibilities. Chain mobility requires changes, in infrastructure (such as bus stations), in technology (such as tramways in urban areas), but also in social and organizational processes such as collective car ownership (car-sharing), the integration of public transport systems, and the introduction by firms of transport management systems for their employees.

Finally, public governance's role in promoting SD is not just a technical and administrative challenge, nor is it something that public servants can do quietly and effectively out of public view. On the contrary. It is a process that requires societal decisions about desirable lifestyles and how benefits and burdens should be shared among different communities and generations, and among the inhabitants of this planet (Meadowcroft, 2007). A summarized concept of governance for sustainable development is illustrated in Figure1.
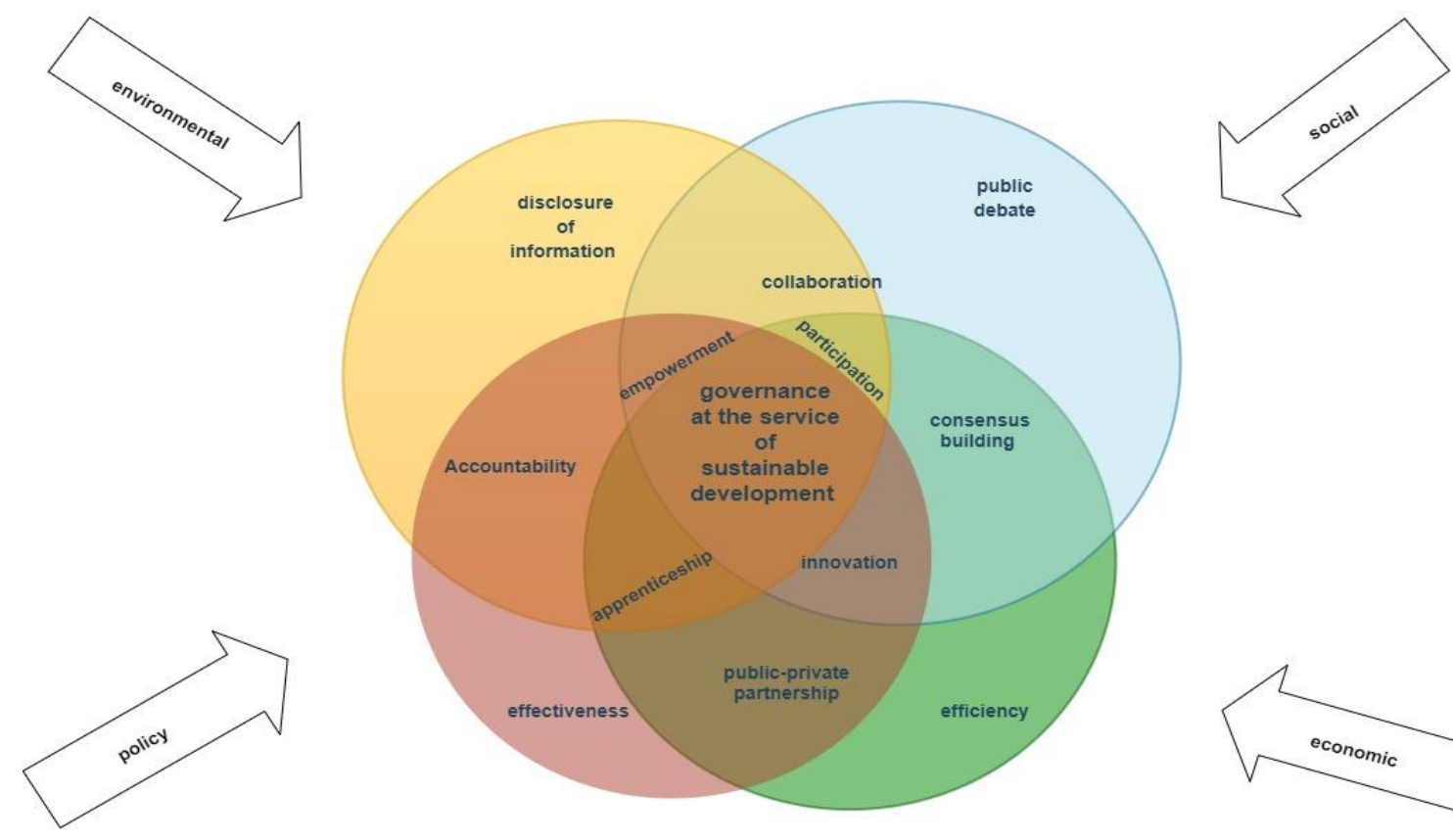

Figure 1: Illustration of the governance concept of sustainable development. (Source: own elaboration)

\section{Agenda 2030: A new paradigm for the United Nations}

The new UN Agenda 2030 results from the Millennium Development Goals (MDGs) and the Rio + 20 conference in 2012. Between the Rio summit in June 2012 and the special summit on sustainable development in New York in September 2015, the United Nations took a historic decision by adopting this Agenda 2030, which is considered as a universal action plan adapted to the new needs of emerging countries by integrating ecological and climate awareness. In its initiators' eyes, experts from the United Nations represent a unique and unprecedented framework for people, the planet, and prosperity (Dobrescu, 2017). 
Characterized by a great awareness of the real threats from the depletion of natural resources and the multiplication of environmental disturbances (Meadows et al., 1972) that societies will face, this Agenda 2030 shapes global development policy and actions for the next 15 years. It covers topics ranging from environmental education, and its objectives challenge both developed and developing countries.

The successful implementation or integration of these objectives into national policies and strategies is intimately linked to the global partnership. The global alliance facilitates intensive engagement worldwide, involving governments, civil society, the private sector, the UN system, and other stakeholders. However, countries working in partnership with other countries certainly learn from each other's implementation challenges.

For this to happen, each country will be responsible for the highest degree of its development. Indeed, each State must henceforth take its share of responsibility, not only financial but transformative of its mode of production and consumption (McMichael, 2016). Given the capacities, realities, and development levels of these different countries, the Agenda 2030 approach requires coherence and coordination to achieve the Sustainable Development Goals. More broadly, national policies and strategies should remain consistent with international commitments and rules.

Different approaches, visions, and models in each country depending on national circumstances and priorities for achieving sustainable development. But, in the context of poverty and eradication, the transition to sustainable development must be carried out as a joint action as a whole. Each country chooses an appropriate approach under national development plans, policies, and priorities at the national level. At the global level, coherence between national policy processes and supranational frameworks must be supported by an enabling international economic environment: coherent financial and monetary systems strengthened and improved global trade.

\subsection{The significant themes of sustainable development according to Agenda 2030}

Agenda 2030 includes 169 targets and 232 indicators grouped into 17 themes called Sustainable Development Goals (SDGs), identified by colored logos (Figure 2), and a declaration text articulating the principles of integration, universality, transformation, and global partnership. It was created through a unique global process of an open-ended working group, which jointly developed the 17 SDGs that were subsequently endorsed by all UN member states (Beisheim, 2015). By 2030, the SDGs, with their sub-goals, serves as an international guideline for progress. This is true for the whole world, even for the materially rich countries, because the SDGs are universal. They aim to balance the social, environmental, and economic dimensions of sustainable development. They provide a social basis for Humanity while ensuring that human development takes place within the Earth's biophysical limits (Rockström et al., 2009).
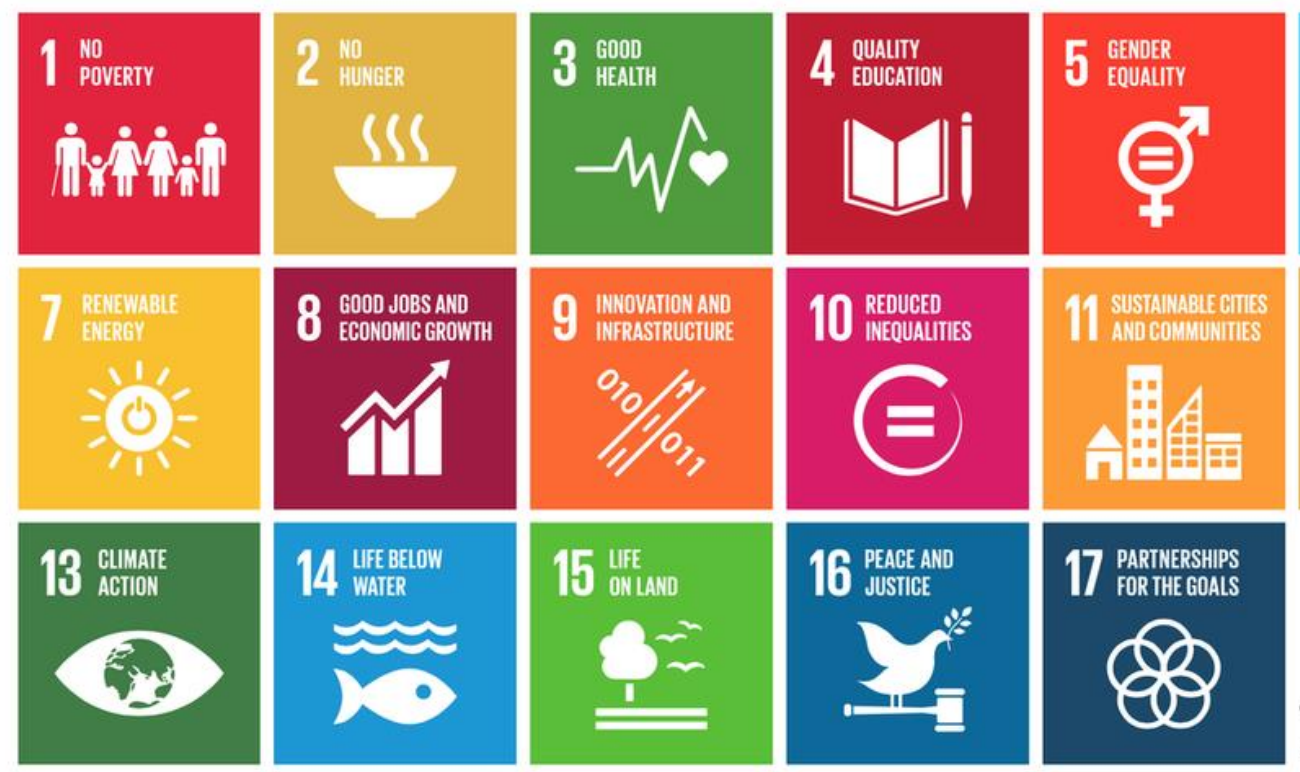
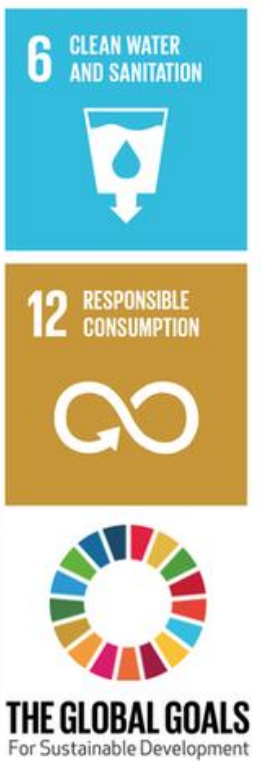

Figure 2: The 17 primary sustainable development goals of Agenda 20303

\footnotetext{
${ }^{3}$ United Nations, consulted on 11/08/2020 in: https://www.un.org/sustainabledevelopment/fr/health/
} 
According to UN experts, each objective illustrates a central theme of Agenda 2030. The first theme of the SDG1, "no poverty," underlines the different dimensions of poverty. It is an incredibly ambitious goal. The Agenda satisfies the most existential basic needs (e.g., overcoming extreme poverty) (Dückers, 2017). The second theme relates to food consumption. The fight against hunger, the improvement of nutrition, and sustainable agriculture are at the heart of SDG 2. What will have to be produced tomorrow will be mainly linked to what will be consumed, wasted, thrown away, or recycled. Besides, food security is undoubtedly necessary for health. This third theme addressed by SDG 3 means, on the one hand, enabling optimal physical health and, on the other hand, maximum mental health or subjective life satisfaction. Theoretically, severe nutritional deficiencies are incompatible with the health dimension: infant and maternal mortality, infectious diseases, etc.

All the more so as this international treaty now makes it possible to apprehend education's dimension in the broadest sense. This is a critical factor in the ability to participate effectively in development. In examining SDG 4, it became clear that it questions the educational model of tomorrow and considers it more as a means to achieve the other objectives of sustainable development than as an end. This goal calls for all boys and girls to access quality education by 2030 and declares discrimination against women as an obstacle to sustainable development. The elimination of all forms of discrimination is also included in the list of targets in SDG 5. The latter also considers equality aspects, notably in equal opportunities or nondiscrimination, again focusing on gender equality.

This international treaty's sixth objective aims to "ensure the availability and sustainable management of water and sanitation for all." Based on this text, water quality and quantity are at the heart of complex equations involving all local and global climate issues (Caron, 2020). Clean water is essential for humans and the natural world. Poor sanitation, poor hygiene, and inadequate infrastructure contribute to disease and millions of deaths each year (CCSI, 2016).

Achieving this goal goes beyond making water and sanitation services available to all communities; it involves measures that ensure sustainable management of water resources (Chitonge et al., 2020). Water management is a challenge. And companies, governments, multilateral agencies, civil society organizations, the local community, and scientific research institutions can work closely together to share water use information and find solutions. In addition to the notions of adequate and sustainable water management in SDG 6, SDG 7 presents a challenge to improve the availability of reliable energy for those who do not have access to it while minimizing negative impacts on the planet. Access to energy is an essential component of the Agenda, an element of sustainable development for many other goals, and a significant contributor to climate change.

Solar energy is the most popular energy source in renewable energy sources, followed by hydroelectricity. These are at the heart of much sustainable development (McCollum et al., 2018). Indeed, the development of renewable energy production could contribute to improving health (SDG 3) by reducing air pollution (Braspenning Radu et al., 2016), but also to economic progress and the creation of new decent jobs (Fankhauser et al., 2008), the eighth theme outlined in SDG 8. This goal represents a golden opportunity to achieve full and productive employment and decent work for all women and men by 2030. The three main elements of this goal are: improving engagement and providing decent job and social protection for all, supporting green growth, and promoting sustainable tourism (Temmer \& Wiebe, 2018). It is clear that a strong economy and quality work opportunities are important aspects of a dynamic country and are also linked to the achievement of the SDGs on poverty reduction (SDG 1), health and well-being (SDG 3), quality education (SDG 4), and gender equality (SDG 5). At the same time, sustainable economic growth calls for sustained investment in infrastructure and innovation, which is the focus of SDG 9. Under this objective, most relevant climate actions focus on building new infrastructure and upgrading existing infrastructure. To this end, issues such as resource efficiency, green industry promotion, and revision of building codes and standards are particularly important (Dzebo et al., 2019).

Another priority on the Agenda reinforces doubts about achieving ecological sustainability and mastering climate change: reducing inequalities between countries (SDG10), promoting the "sustainable well-being" of people in the dimension of equality. This objective 10, complementary to SDG 5, addresses inequalities of all kinds (social, regional, ethnic, etc.) within and between countries. It brings the idea of a society where everyone enjoys the benefits of economic growth. To this end, the Heads of State and Government declare in Agenda 2030: "Disparities are widening within and between countries. There are enormous differences in opportunities, wealth and power" (UNGA 2015: paragraph 14). According to these leaders, poverty persists, and inequalities increase despite a significant poverty reduction in many countries, particularly in the least developed countries. Indeed, the nature of economic growth can sometimes be a source of inequality (Hossen \& Khondker, 2020). Therefore, despite a high growth rate, it is not always easy to reduce disparities. The equality dimension is unlikely to progress if the richest become even more prosperous as the poorest become less poor. It is just as necessary to pay as much attention to the inequalities between rich and poor regarding the latter's situation. 
On the other hand, global sustainability's central issues cannot be discussed without considering sustainability at the urban scale. The Agenda for Sustainable Development calls for concerted action at the scale of cities and communities to achieve long-term development goals and bring direct benefits to people's quality of life. Highly ranked among the 17 goals, SDG 11 "Sustainable Cities and Communities" emphasizes the importance of more sustainable urbanization processes. The global trend is one of increasing urbanization as more and more people move to cities. Cities account for $55 \%$ of the population and produce $85 \%$ of the world's GDP and $75 \%$ of greenhouse gas emissions (Vaidya \& Chatterji, 2020).

However, if the current urbanization trend continues, it will be almost impossible to stop climate change. Therefore, different climate change mitigation activities should be considered in cities, such as commitment to clean fuels, public transport, and electric vehicles. This implies a review of production and consumption patterns as a strategy to improve the planet's environmental quality. In this respect, this eleventh objective could be usefully complemented by SDG 12 aimed at "ensuring sustainable consumption and production patterns." Globally, the goods and services consumed are among the major causes of environmental degradation throughout their life cycle, from raw material extraction, production, and transport to use and end of life (Gardner et al., 2019). In this regard, SDG 12 points out the crucial issues of combating climate change: it includes in its underlying targets the need for improved waste management (12.4) and the reduction of waste generation through recycling and reuse (12.5).

These themes are added to those relating to the fight against climate change (SDG 13) and the conservation of aquatic (SDG14) and terrestrial (SDG 15) biodiversity. Then there is SDG 16, which falls within the context of the rule of law's securitization in international practice. This objective includes a series of indicators related to violence and crime, including the following objectives: "significantly reduce all forms of violence and related deaths everywhere" (16.1), "significantly reduce financial and illicit arms flows, strengthen the recovery and restitution of stolen assets and combat all forms of organized crime" (16.4), "significantly reduce corruption and bribery in all its forms" (16.5). Finally, SDG 17 concludes on the most urgent issues for the "strengthening and revitalization of the 'global partnership."' This last objective of the UN Agenda is one of the most crucial SDGs because it aims at much higher goals than its predecessor. It sets goals for shared and inclusive global governance based on partnerships, particularly controlling common global resources crucial for achieving all the SDGs.

In light of the above, it is clear that Agenda 2030, with its 17 sustainability goals, is not exactly "user-friendly" (Wölkner, 2019). The topics are too complicated, where "everything is linked to everything else" and where each objective is a precondition for progress on the path to sustainability. Put another way, all SDGs will be able to see the direct and indirect links. Juknevciene and Krateivaite (2012) give an example of the fundamental connection between Goal 4, "quality education," and Goal 16, "peace, justice, and effective institutions." It is proclaimed that institutions could make a substantial contribution to improving health conditions. Simultaneously, as one of the main factors of development, education is essential for peace, the consolidation of democracy, good governance, and the rule of law at all levels. And both are linked to Goal 5, "gender equality"; education and good governance contribute to the fight against terrorism, human trafficking, violence against women, and all forms of racism.

In parallel with the SDGs' interconnection, it is sometimes mentioned that the multiplication of SDGs can also make the Agenda less user-friendly. It seems interesting to reduce the thematic areas (Dückers, 2017). As shown in Figure 3, it was rightly possible to assign all 17 goals to the seven thematic areas. Figure 3 will then serve as a starting point for a comparison focusing on letter 53 and Agenda 2030. 


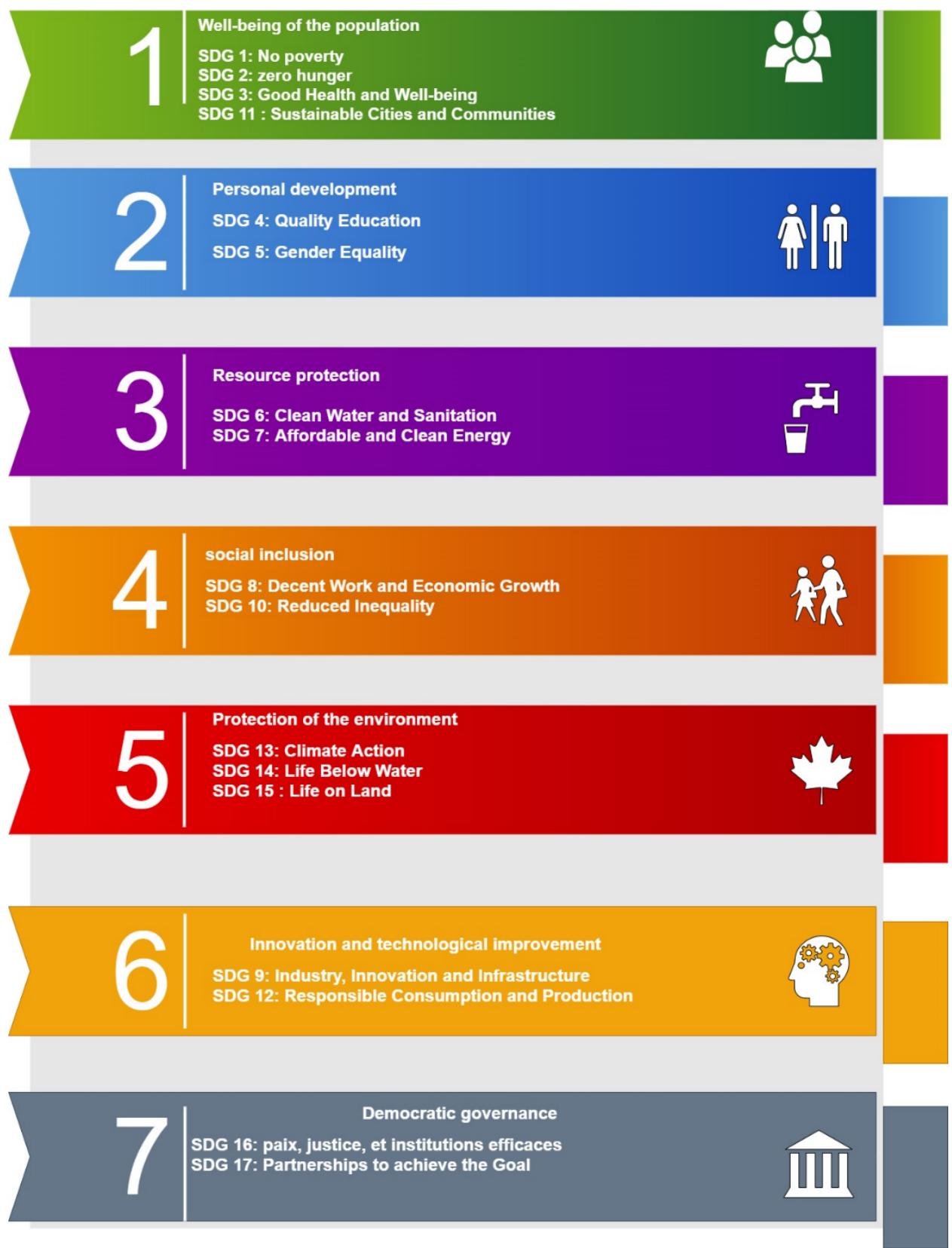

Figure 3: The seven thematic areas grouping the 17 objectives of Agenda 2030 (Source: own elaboration).

\subsection{Agenda 2030: a necessary dialogue between governance and sustainable development?}

Long excluded from public Policy, the gradual inclusion of good governance in SDGs began in the late 1980s (Dhaoui, 2019). Faced with the aggravation of socio-economic problems such as "poor quality education and training, food insecurity, climate change, pollution, poverty and terrorism," the United Nations' Sustainable Development Agenda to 2030 has again reinforced the demand for governance systems capable of putting society on a more sustainable path.

Committed to good governance and its vital role, SDGs 16 and 17 emphasize the importance of developing a democratic government. They address the notion of authority in two dimensions (Châtaigner \& Caron, 2017):

The first dimension, addressed by Goal 16, emphasizes institutions' crucial role based on good governance. Knowing that "good governance" includes the relations between the State and the population, it is a question of developing democratic governance that can integrate the driving forces, i.e., governments, central and local public actors, private actors, and civil society actors in any analysis of the steering of society (Lemos \& Agrawal, 2006). This process can already promote the 
principles of participation, transparency, accountability, and dialogue between leaders and citizens since it can only promote each State's effective implementation of sustainable development objectives.

The second dimension is that of multi-stakeholder partnerships that place people and the planet at the heart of their concerns. This form of governance, which is at the heart of SDG 17, addresses the challenges of partnerships for the implementation of development projects between States and companies (PPP) and between States and NGOs. Diversified partnerships enable the actors to master the knowledge and innovations necessary to develop their countries more rapidly. Overall, Objectives 16 and 17 were considered a prerequisite for the achievement of several SDGs. As such, SDG 16 "peace, justice and effective institutions" represents a cross-cutting theme that cuts across the whole of Agenda 2030 (Tosun \& Leininger, 2017) as institutions could make a substantial contribution to the maintenance of human rights, environmental protection, stable macroeconomic conditions, management and resource mobilization for essential public services (Juknevciene \& Krateivaite, 2012). It can be noted, for example, that the content of this objective, which calls for civil peace and peace between states, must be associated with objective 10, which aims to combat inequalities, whatever their origin.

The last objective of governance 17, "partnership for the achievement of the goals," calls for strengthening the means of implementation to achieve the other goals and a global partnership to work towards sustainable development. Its importance for the other goals is also reflected in its sub-objective 17.14, "improving concerted policies for sustainable development." Policy coherence for sustainable development refers to the systematic integration of policies, processes, and institutions for the coherent implementation of sustainable development (OECD, 2018). For example, in the case of energy, policy coherence is a concept for understanding the extent to which energy policy objectives and other policy objectives (economic, environmental, social) support or undermine each other (Tosun \& Leininger. 2017; Meuleman, 2019). In this case, the Policy of promoting rural electrification undoubtedly contributes to the development of rural infrastructure "SDG 9" and consequently to the achievement of SDG 4, which calls for inclusive and equitable education.

\section{Methodology}

The study presented in this article is comparative. To do so, we began with a textual analysis 4 of 117 passages of the letter 53, based on the critical words of Head of State Ali. The textual content of each extract was examined to identify the thematic areas of SDGs, namely, Population Welfare, Personal Development, Resource Protection, Social Inclusion, Environmental Protection, Innovation and Technological Improvement, Democratic Governance". These passages were then matched with almost all the SDGs of Agenda 2030. Our study highlights the similarities between the promising governance approaches to sustainable development in these two charters and their most revealing divergence points.

\section{Comparative study between Letter 53 and Agenda 2030 5.1 Background and description of the Letter}

Finalized in 658, Letter 53 of the Fourth Caliph Imam Ali Ibn Abi Taleb recognized the appreciation, enthusiasm, and admiration of many politicians, economists, researchers, UN agencies, and civil society actors engaged in the field of human rights. The Letter was sent to Malik al Ashtar5, whom Imam Ali had appointed governor of Egyptian territory when the State of Egypt became disrupted.

History books tell us that the year 632 marked the starting point of expanding the Muslim world6. Around 656, during the rule of Caliph Ali (Buresi, 2018), Arab conquerors subjugated all of Egypt. At that time, Egypt was ruled by Muhammad ibn Abi Bakr, son of the first Caliph Abu Bakr. The head of State Ali informed him that he would replace him with Malik Al Ashtar, whom he considered better resisting the civil war that dominated Egypt (Shah-Kazemi, 2006).

According to most accounts, when Malik traveled to Egypt, the Imam gave him a very long letter that shows how to treat Egypt justly. It is in the form of a text in most editions of the Nahj al-balāgha (Shah-Kazemi, 2006) containing nearly 3500 words, making it one of the book's most comprehensive documents. This 53rd Letter of the Nahj Al-Balagha, carefully written and filled with advice and instructions, reveals an outstanding head of State with an economic vision that would support the shaping of a just, equitable, and viable society, and its emphasis would be placed on the social as well as the economic and ecological pillars. Therefore, the teachings of Imam Ali have enlightened Malik Al Ashtar on the path to take so that he can properly fulfill his role as governor.

\footnotetext{
${ }^{4}$ this analysis was carried out on the basis of the French translation of the letter 53.

${ }^{5} \mathrm{He}$ was also known as Malik bin al-Harith an-Nakha'i, a native of Yemen and one of Ali ibn AbiTalib's most faithful companions.

${ }^{6}$ See "Siège d'Alexandrie (641)", [online], https://fr.qwe.wiki/wiki/Siege_of_Alexandria_(641)
} 
In this work, the reader will find plural in its conception, a summary of fundamental principles of good governance. It deals with the duties and obligations of leaders, their primary responsibilities, the concerns of citizens for social justice aspects of the economy, and the control of secretaries and subordinate staff: the distribution of work and tasks between the different branches of the Administration, their coordination and cooperation with the center. This masterpiece wanted to teach the world that these principles could be put into practice. The remainder of these instructions also allows us to see how current these realities are and how our governments are out of step. In this regard, it is sad to ask ourselves why academics and researchers are not interested in the works of this beautiful Letter. Whereas, Kofi Annan stated that this charter, even after 14 centuries, has remained the best treatise on justice.

A review of Imam Ali's writings reveals that the Letter contains 117 passages that denote relevant principles. His instructions begin with broad guidelines, with the following words: "To perceive the entrances of the state, fight its enemies, improve a lot of its inhabitants and ensure the prosperity of the country. ». Through his simple words, we also discover that this Head of State had a significant role in establishing the governance framework for more egalitarian and environmentally friendly development and growth.

Despite being a conservative society member, Imam Ali invoked sustainable development governance issues similar to contemporary themes. Attentive to human prosperity, his message was addressed to the governor, whose welfare is the ultimate goal of all development policies. In his Letter detailed in his instructions to Malik, it is clear that some of the values expressed are reflected in the 2030 schedule, in particular, the principle of non-discrimination, the promotion of well-being, the preservation of ecosystems, and others. From our perspective, it does not seem exaggerated to assume that this is the first document dealing with the SD issue.

\subsection{Results and discussion}

In a comparative framework, we will analyze the 53rd Letter of the Nahj Al-Balagha and the UN Agenda 2030. The choice of the Agenda is due in large part to the number of common topics that address important questions regarding the vision, objectives, and particularities of sustainable development of nations. This work focuses on 13 Sustainable Development Goals (SDGs), which, at first glance, are expressed in the Letter, namely SDG1, SDG 2, SDG 3, SDG 4, SDG 5, SDG 9, SDG 11, SDG 12, SDG 13, SDG 14, SDG 15, SDG 16, SDG 17.

Given that, as noted above, most SDGs are considered to be associated with central themes, we focus here on mapping some of these themes to letter 53. As a counterpoint, as will be seen in the rest of the text, the exact structure of the Letter allows a thematic partitioning that facilitates comparative analysis with Agenda 2030. Pragmatically, based on a textual analysis of 117 passages 7 of the Letter, we identify below the following five themes; the well-being of the population, personal development, environmental protection, technological innovation and improvement, and democratic governance, and then, through these themes, we examine the interconnections between the SD objectives of letter 53 and those of Agenda 2030.

\section{A. The well-being of the population}

(38) "...to prosper...The needy and the underprivileged, for their part, have the right to receive aid and assistance...".

(57) "Take care of the earth...for the abundance of the products of the earth and the prosperity of the producers condition the well-being of others...".

(58) "... peasants can complain about ..., calamity, water shortage, fog, flood or drought...."

(74) " ..... To watch over the deprived and deprived class; that of the poor, the needy, the miserable and the disabled".

(80) "Find out about the status of orphans and elderly people ........."

The concept of sustainable development that has been embodied in the "Agenda 2030" Agenda starts with non-poor (SDG 1), safe (SDG 2), healthy (SDG 3) men. These three pillars seem to be decisive for social prosperity. Well-being is everywhere! It is at the heart of politicians, economists, journalists, academics, and other societal actors. It is increasingly present in speeches and actions related to sustainable development.

Having detailed, in these passages quoted above, this is in line with Imam Ali's earlier idea, and the three pillars are quite suitable for his reflection. Indeed, the leading thinker of the SD paid, first of all, special attention to the social progress of human beings. He knew that the well-being of every segment of society should be guaranteed. Moreover, this Letter repeatedly reminded the governor of Egypt that all classes in general and the lower class should define SD policies.

${ }^{7}$ the selected passages are then translated into English. 
For the first and second pillars, the short but instructive quotes $38,57,58,74$, and 80 highlighted an essential and even crucial aspect of food security. These texts' central point is to eliminate extreme poverty in all its dimensions (access to water, elimination of famine, health, etc.). The Imam wanted Mālik to pay special attention to people who have no resources: the destitute, the infirm, the orphans, the elderly. In this sense, it seems that the conditions for receiving relief and aid, two essential keys, which preoccupied the fourth Caliph, strongly wished for evolution towards increased social rights protection. We believe that these two words are central to the idea of food security.

Then gradually, and to the same end, the fourth Caliph continued to support economic growth based on sustainable agricultural systems. Based on text 57, we were able to interpret this question in depth. To achieve sustainable food security, its orientations were identified, more precisely, Imam Ali considered that eradicating hunger lies with sustainable agriculture. The promotion of food security and sustainable agriculture was public Policy. Governors needed to keep a watchful eye on sustainable food systems to ensure stable food supplies and provide everyone with balanced nutrition access.

In dark and troubled times, it is essential to note that Imam Ali alerted his new governor to floods and water shortages (passage 58); he was still worried about a food crisis. This situation is mainly fostered by conflicts and aggravated by droughts or other weather phenomena. The impact could be catastrophic for millions of people, and violence is spreading mostly to rural areas, with adverse effects on food production and availability (FAO, IFAD, WHO, WFP \& UNICEF, 2017).

This statement made by this Head of State is certainly welcome in this regard, significantly if in 2016 , food security sharply deteriorated. According to FAO estimates, the number of chronically undernourished people worldwide has increased from 777 million in 2015 to 815 million in 2016 (FAO, IFAD, WHO, WFP \& UNICEF. 2017). His speech leads us to understand that it is imperative to find sustainable production modes and consumption solutions. These modes allow us to consider, therefore, other approaches to managing food chains.

When we arrived at the last pillar, we stopped again at texts 57, 58, and 80, and we retained that health promotion and SD are two notions to be approached in public action. Imam Ali wanted to teach everyone in general and the new governor of Egypt that undernourishment and poor health are closely associated. In fact, after the civil war in Egypt (Irdas, 2018), the lack of water and sanitation could increase the risk of disease; gradually, these problems could weigh heavily on the Egyptian labor force's productivity. Thus, when it extended to a large part of the population, the growth lag affected Egypt's economy. In summary, any leader reading this Letter will recognize that the great thinker Ali addressed agricultural inputs' effects on people's health. It is clear from passage 57 that the performance of agricultural activity leads to better health. It is no longer just a question of producing more and measuring this performance in terms of the quantities produced and better understanding how particular production choices translate into disease prevention, reduction of preventable deaths, climate change mitigation, and health promotion, etc. It is no longer just a question of producing more and measuring this performance in terms of the quantities produced. Later, the Imam asked Malik to learn about orphans' status and look after the underprivileged class. For our part, the lesson is clear: health is influenced by poverty. Poor health threatens children's rights to education, limits men's and women's economic opportunities, and increases poverty within countries. As Kerras et al. (2020) commented, health sectors' development increases citizens' well-being. States that want to promote sustainable social and economic development must improve health outcomes.

\section{B. Personal development}

(9) ".....they are of two kinds: a brother in God or else or else a fellow human being,...".

(74) " ..... To watch over the deprived and deprived class; that of the poor, the needy, the miserable and the disabled".

(34) "Know that your constituents find themselves in categories that are intimately linked to each other in such a way that none of them can be healthy if the others are not...... ... »

(76) "The furthest away has as many rights as the nearest, and you are responsible for the share of each."

(80) "Find out about the status of orphans and elderly people .........."

(81) "Devote part of your time to hearings given without the presence of your soldiers and collaborators, in .......order to allow them to express themselves without fear or hesitation.

Concerning personal development and sustainable development, the Letter distinguishes three main orientations: firstly, access to quality education (SDG 4), secondly, the application of the right to equality (SDG 5), and finally, the right to freedom of expression.

On the first aspect, we are again stuck with sentences 38,74 , and 80 , demonstrating that education, like health, is an SD sector. We see that they address poverty, food security, health, and education simultaneously in this set of sayings. From 
Imam Ali's point of view, these five components are intimately linked and contribute powerfully to social cohesion. He was well aware that severe physical and mental health shortcomings have severe consequences for a child's participation and school learning. Besides, Imam continued to clarify to his governor that ending poverty and pandemics inevitably requires access to quality education for all. Education contributes to the maintenance of health, and health provides the necessary conditions for learning, just as food security in terms of adequate access to food and healthy food has positive health and development implications.

For the second aspect, the most famous saying 9 contains a social protection program based on equality and nondiscrimination. Imam Ali was severe towards this act. There can be no question of accepting any distinction of sex, race, nation, or religion. Indeed, in the eyes of this Imam, people are equal in creation as well as in religion. This crucial point will be reinforced later in several UN reports (ONU, 2016; ONU, 2002) on sustainable development. Again, one cannot help but notice the similarity between Imam Ali's description of non-discrimination and UN conventions. These conventions impose the principle of equality as a norm that sets benchmarks to protect Humanity from violence. The equality component referred to in this passage is closely related to "fraternity" in the sense of solidarity. Finally, the solidarity of the materially rich with the poor leads to greater equality in the distribution of goods and income in particular (Beisheim, 2015).

The notion of equality becomes even more apparent if one looks at Directives 20 and 76, which expressly set out fundamental ideas about the principle of equality. All the more so since passage 76 invites us to revisit the question not only of inequality at any source: social, racial, sexual... but at all levels: local, regional, national, international (as cited in passage 10 of Agenda 2030).

Finally, on the last aspect, paragraph 81 invites leaders to place the principle of freedom of expression at the heart of their priorities. We come to a subtle point in the Letter, a moment where leader Ali attacks, without taboo and with determination, the issue of freedom of opinion. In the Imam's enduring vision, personality development requires more access to free education and equality as much as freedom.

Subsequently, the European Convention on Human Rights (CEDH, 1950) goes in the same direction and works in the same spirit. In this perspective, article 10, paragraph 1, of this convention states the following: "Everyone has the right to freedom of expression. This right shall include freedom to hold opinions and to receive and impart information and ideas without interference by public authorities and regardless of frontiers. "

In light of this text, it is clear that freedom of expression implies the right to express what one thinks without fear or anxiety freely. The dimension of liberty is undoubtedly indispensable for the development and perfection of each individual. It refers to the hypothesis according to which the individual can behave according to his discretion, which is already sufficient to act according to one's appreciation. It is on this rule that Imam Ali's vision is based. An in-depth analysis of his message suggests that he sees governors' interaction with people as a favorable human development element. Hence, the need to federate public and private sector decision-makers' efforts to invite people to organize meetings or debates, share their concerns, express their demands, and participate in the decisions that affect their lives.

Moreover, many of the 17 Sustainable Development Goals set out in Agenda 2030 are related to the right of freedom of expression without providing a precise definition. In particular, we believe that Goal 16 is the most appropriate, emphasizing this concept's need.

In this vein, we will find that the Letter is at the origin of this concept. Moreover, leader Ali, a defender of freedom of expression, used an assortment of words, and approved this culture to be excessively noble to be a simple culture. On the contrary, it is so deeply rooted in society's values that it is associated with all other sustainable development dimensions.

\section{Protection of the environment}

(57) "Take care of the earth...for the abundance of the products of the earth and the prosperity of the producers condition the well-being of others...".

(58) "Be more concerned about the good condition of the land than about the entries .... farmers can complain ...... about a shortage of water...... about flooding or drought.... »

These passages explicitly state that the ecosystem approach is a sustainable land (SDG 15), water (SDG 14), and living resources. The issue is particularly crucial for public action strategy: it is then a real challenge to develop governance models that make the management of natural resources useful for the great benefit of more sustainable development paths.

Recent crises are not only economic and social. But the most worrying situation is the ecological nature of the problem. In connection with global warming and greenhouse gas emissions, the most recent economic and environmental data testify to the difficulty and complexity of reconciling "environment-economy-society" issues. 
With determination and despite its great age, Letter 53 tackled the subject of sustainable management of land and water when the term sustainable development began to germinate only three centuries ago, let alone protect the environment. As head of State, Imam Ali ordered his governor Malik Al Ashtar in passage 57 to adopt an effective land-use policy, certainly, but serene to ensure the preservation and sustainable use of different types of terrestrial ecosystems (forests, mountains,). It reminds its governor that future generations have the right to enjoy the same conditions as their ancestors, i.e., the right to uncontaminated, intact, and exploitable land.

In this respect, the fourth Caliph combined in passage 57 between the words abundance and prosperity to explicitly unveil an economic concept that measures the importance of the available stock, namely the notion of "reserve." In particular, this directive must be understood in its most profound sense: once the primary resources extracted from the soil are depleted, they will threaten ecosystem services and inevitably weigh on contemporary populations and future descendants. Furthermore, passage 58 discloses that Imam was concerned and seriously took climate-related natural disasters (SDG 13) that could eventually affect future generations, including desertification, drought, floods, etc. In this regard, he called upon his governor of Egypt to be increasingly concerned about land and the water ins and outs while seeking concrete solutions to reverse the trend of land and water degradation (SDG 12). For Imam Ali, without the sustainability of these resources and preserving the ecosystems to which they are linked, it is impossible to talk about citizens' well-being and initiate a sustainable development strategy that protects the environment.

\section{Innovation and technological improvement}

(33) "Regularly frequents the people of science, often discusses with the wise men to be able to consolidate the good principles which ensure the good running of the country .... "

(46) "Then recognize for each one what is due to him. Never attribute someone's work to someone who is not the auth or and do not diminish its merits....... »

(69) "Watches over merchants and artisans recommends that they be treated with kindness, whether they are established, itinerant, or manual workers. Because they are sources of goods and profits..........

The defender of sustainable development objectives explains his idea in this part of his approach with incredibly striking passages. Through his words, the Imam unveiled the theme of innovation. Indeed, it is inadmissible to support SD if there is no innovation. Thus, these words made it clear that this significant component is becoming aware of the scarcity of resources and the rise of global disasters connected with climate change.

The innovation component is present in each of the sayings. First, the text "33" is notable for its use of network-based innovation. At all levels, innovation must be network-based to address specific environmental and climate issues. Imam Ali's perspective on this innovation is demonstrated by his interest in science, professionals, and experts. He advocates choosing versatile members, experienced in various activity fields, and ready to update their knowledge. Such innovation involves cocreation that aims to stimulate new ways of solving problems or meeting social needs through a process of participation and collaboration.

Second, paragraph 46 proclaims that one of the significant challenges around sustainable development is undoubtedly property rights. The latter tends to be perceived as a priority on which to base the invention and dissemination of solutions adapted to each problem.

Ownership means everyone's right to freely enjoy and dispose of their property (Domas-Descos, 2012). And like any sustainable development approach to succeed, it must guarantee natural human rights, particularly property rights (Lequette et al. 2007). More than a thousand years ago, this text from the Letter included numerous recommendations relating to integrating property rights into this concept.

When the misappropriation of industrial and/or intellectual property can be a source of many disputes and, therefore, a brake on innovation, it is worthwhile, for there to be economic growth through innovation, to draw inspiration from the legal texts formulated by Imam Ali which help to enlighten leaders on this issue. For this reason, the legislation guarantees that the innovator will be able to benefit from his invention.

Finally, focusing on saying 69, we understand that the Imam then describes traders and artisans as project carriers and innovation producers. We observe how he encourages his leader to accept and then support the useful initiatives that the traders and artisans propose. The governor must consider each initiative as a transformative project taking into account social and environmental requirements. Therefore, his role is twofold: to support any innovation support policy aimed at the "producers" of innovation and contribute to innovation diffusion in all economic sectors. Such an approach was set out in the 
Letter. It will also open up the possibility of increasing the productivity and efficiency of production systems, which is generally convergent with resource savings.

\section{E. Democratic governance.}

(35) "Armies are, by the Grace of God, the bulwark of the people, the glory of the rulers, the strength of religion, the guarantor of security; the affairs of the nation can prosper only by their presence. "

(36) "Armies can only be established if they are given their share of the zakat which God has given them, that they may be strong in the battle against the enemy..........".

(37) "But neither the armies nor the people could be useful without the support of a third category, that of magistrates, scribes, and agents of public and private affairs, given the contracts they establish and the trust placed in them concerning the affairs of the State as well as private individuals. "

By bringing together the passages associated with sustainable development, we are approaching its hardcore, we believe. After taking stock of the notion of innovation, we turn our attention to the idea of democratic governance. It is intimately linked to a credible judicial system, peace, and national security (SDG 16) conducive to sustainable development achievement. It is part of frameworks open to partnership with a wide range of actors (SDG 17).

National security is a vital element of sustainable development, which does not contradict the other principles mentioned above, all of which are inseparable and indispensable for the country's prosperity. On this point, the United Nations General Assembly of 2015 attests that: "Bad governance breeds violence, insecurity, and injustice. Imam Ali's message corresponded perfectly to this idea, warning his governor that it is inconceivable to achieve an SD goal amid instability and social insecurity (passages 35,36 ). Admittedly, when they settle, they pose a severe threat to a nation's evolution and have a destructive effect on development. Al-Ashtar had to consider that the army is the fortress of the people, the strength of religion, and the means of peace.

Then gradually, and to the same end, the fourth Caliph Ali continued to support the armed force. With this in mind, he asked his governor to begin by paying the military properly because they are the only ones capable of protecting the people. Concerned about his quality of life, it was apparent that the soldier and his remuneration should be at the center of the governor's concerns. Al-Ashtar had to ensure his financial independence by providing him with payment so that there would be no opportunity to go to others for his needs. Imam Ali envisioned a fair and consistent remuneration system for civil servants that emphasized competence and merit to achieve this.

Most importantly, there is also, and incredibly, the judiciary, one of the pillars of democratic governance. Passage 37 gives a decisive role to the judicial power. In this passage, the Caliph recognizes that legal security is a fundamental element of law rule. He considered this issue to be of paramount importance because there can be no sustainable development without justice, and conversely, without sustainable development, justice is in danger. It was then incumbent on its administrator to mobilize all relevant means to build independent, integrated and effective judicial institutions. Finally, he considered that these institutions' prosperity could advance society to the pinnacle of economic progress.

This same passage 37 is also intended to reinforce the fact that the multi-actor partnership is not modern. Imam Ali calls out that the sectors of activity are concerned with sustainable development. Indeed, a closer reading of passage 37 shows nevertheless that the achievement of economic and social objectives with high added value undoubtedly passes through cooperation and public-private partnerships and those with civil society. Its expressions indicate that this partnership practice makes it possible to mobilize and share knowledge, expertise, technologies, and financial resources to help the country achieve sustainable development objectives.

Under this passage, the Imam implored his governor Malik Al Ashtar to use these public authorities to involve civil society, citizens, and private companies in partnership projects. He alone can hardly win the SD struggle. He encourages his governor to engage in the political arena to create a favorable environment for trade and public markets' opening to private operators. In this regard, it recommended that Malik Al Ashtar build a climate of trust so that this organizational form of partnership becomes an instrument at the service of its sustainable development policy. With a sense of joint responsibility on all the actors, an environment of trust and transparency is indispensable to the satisfactory outcome of an SD approach. By their very nature, partnerships involve a concordance of organizational units and actors with diverse skills and values, with varied and often opposing objectives. In short, good governance of multi-stakeholder partnership structures, based on clear procedures and equitable sharing of benefits and risks, is for Imam a pragmatic solution to issues related to the economic, social, and environmental development of nations. 
Moreover, the five thematic areas mentioned above represent only a tiny percentage of the Letter. As shown in Figure 4, the proportion is about $4 \%$ of letter 53 for the well-being of the population, $5 \%$ for personal development, $2 \%$ for environmental protection, $3 \%$ for innovation and technological improvement, and $2 \%$ for democratic governance. These somewhat surprising results further underline that the Letter is more interested in other themes related to good governance's fundamental principles. The speech attributed to Imam Ali offers us a rich source of reflection.

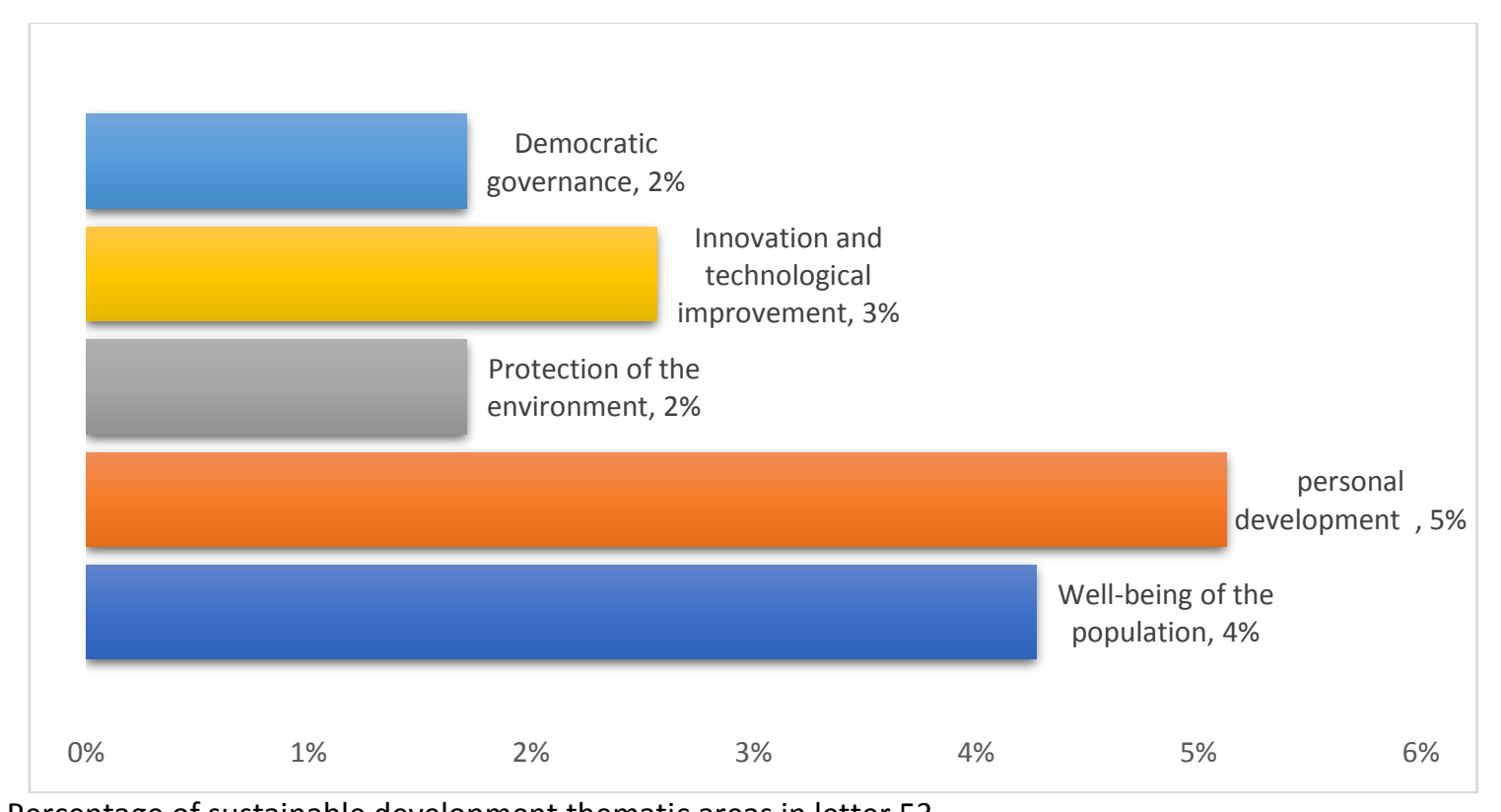

Figure 4: Percentage of sustainable development thematic areas in letter 53

(Source: own elaboration).

\section{Agenda 2030 versus Letter 53}

The comparative analysis between Letter 53 and Agenda 2030 reveals a substantial similarity in their vision of a sustainable society. Our research shows that five themes are shared between these two written documents on sustainable development with ten main objectives. In each of the five goals, we found that both the Letter and the Agenda argue for future Humanity that would be prosperous, sustainable, and egalitarian. There is one main idea that runs through Imam Ali's instructions and the UN Agenda's SDGs, and that is to draw a transformative ambition for our world to make it sustainable and show how to achieve it.

However, there appear to be significant differences in some themes. Although they share common interests, these policy documents have divergence points due to several objectives that are not identical. These are the objectives associated with the three themes of personal development, innovation, and population well-being.

Firstly, in terms of the Letter's meaning, the main emphasis of the theme "well being of the population" is on non-poverty, food security, and good health. Conversely, the Agenda indicates that the importance of urban resilience also contributes to the well-being of society.

Second, the Agenda and the Letter agree that the second thematic area, "personal development," includes quality education and gender equality. However, the Letter also suggests possibilities for freedom of expression.

Thirdly, the two roadmaps for sustainable development differ radically in the theme of innovation. From Agenda 2030, innovation and technological improvement are structured according to two objectives, on the one hand, industrialization and innovation, and on the other hand, responsible consumption and production. At the same time, the Letter recommends innovation based on networks, property rights, and project leaders' support.

The results of the correspondence between the two charters are shown in Table 1. 
Table 1: Comparative table of SD thematic areas between Letter 53 and Agenda 2030.

\begin{tabular}{|c|c|c|c|}
\hline Theme & $\begin{array}{l}\text { Agenda } \\
2030\end{array}$ & $\begin{array}{l}\text { Letter } 53 \text { from } \\
\text { Imam Ali }\end{array}$ & Comment \\
\hline $\begin{array}{l}\text { The well-being of the } \\
\text { population }\end{array}$ & $\begin{array}{l}\text { SDG } 1 \\
\text { SDG } 2 \\
\text { SDG } 3 \\
\text { SDG } 11\end{array}$ & $\begin{array}{l}\text { Passage } 38 \\
\text { Passage } 57 \\
\text { Passage } 58 \\
\text { Passage } 74 \\
\text { Passage } 80\end{array}$ & $\begin{array}{l}\text { Both charters assess the population's well-being } \\
\text { on three critical criteria: non-poverty, food } \\
\text { security, and good health. Also, Agenda 2030, to } \\
\text { ensure well-being, addresses urban development } \\
\text { and sustainable human settlements. }\end{array}$ \\
\hline Personal development & $\begin{array}{l}\text { SDG } 4 \\
\text { SDG } 5\end{array}$ & $\begin{array}{l}\text { Passage } 9 \\
\text { Passage } 74 \\
\text { Passage } 34 \\
\text { Passage } 76 \\
\text { Passage } 80 \\
\text { Passage } 81\end{array}$ & $\begin{array}{l}\text { Personal development is summarized in two } \\
\text { main concepts: quality education and gender } \\
\text { equality. However, according to the letter } 53 \text {, } \\
\text { other elements may be associated with notable } \\
\text { freedom of expression. }\end{array}$ \\
\hline $\begin{array}{l}\text { Protection of the } \\
\text { environment }\end{array}$ & $\begin{array}{l}\text { SDG } 13 \\
\text { SDG } 14 \\
\text { SDG } 15\end{array}$ & $\begin{array}{l}\text { Passage } 57 \\
\text { Passage } 58\end{array}$ & $\begin{array}{l}\text { In this theme, the fight against climate change } \\
\text { and aquatic and terrestrial biodiversity } \\
\text { conservation are central targets for each of the } \\
\text { two charters. }\end{array}$ \\
\hline $\begin{array}{l}\text { Innovation and } \\
\text { technological } \\
\text { improvement }\end{array}$ & $\begin{array}{l}\text { SDG } 9 \\
\text { SDG } 12\end{array}$ & $\begin{array}{l}\text { Passage } 33 \\
\text { Passage } 46 \\
\text { Passage } 69\end{array}$ & $\begin{array}{l}\text { According to Imam Ali's Letter, innovation based } \\
\text { on networks, property rights, and support for } \\
\text { project leaders are three essential elements to } \\
\text { strengthen innovation and facilitate the } \\
\text { achievement of sustainable development. } \\
\text { Regarding Agenda 2030, specific actions are } \\
\text { requested to improve innovation, namely, } \\
\text { research and development in industry and } \\
\text { innovation and the significant transformation of } \\
\text { sustainable consumption and production } \\
\text { patterns. }\end{array}$ \\
\hline $\begin{array}{l}\text { Democratic } \\
\text { governance }\end{array}$ & $\begin{array}{l}\text { SDG } 16 \\
\text { SDG } 17\end{array}$ & $\begin{array}{l}\text { Passage } 35 \\
\text { Passage } 36 \\
\text { Passage } 37\end{array}$ & $\begin{array}{l}\text { According to the two sustainable development } \\
\text { roadmaps, technology governance encompasses } \\
\text { providing access to justice for all, promoting } \\
\text { security and peace, and fostering multi- } \\
\text { stakeholder partnerships. }\end{array}$ \\
\hline
\end{tabular}

\section{Conclusion}

The results of this study suggest that there are sufficient similarities between Letter 53 and Agenda 2030 in terms of how to develop an effective and efficient strategy for good governance for sustainable development. Nevertheless, there are some differences between the two charters regarding specific themes' objectives and a growing distinction between the SDGs grouped under Innovation and Technological Improvement.

Strange as it may seem, our literature search reveals that many academics and specialists think that environmental governance is a relatively recent concept. However, this reality is inaccurate since the remarkable parallels of Letter 53 with Agenda 2030 clearly show that, in the past, Imam Ali as head of State provided his governor of Egypt with many indispensable and decisive pieces of advice to develop a comprehensive approach to achieve economic, social and environmental development. At this point, it is striking to note how the notion of sustainable development is not recent and was part of Imam Ali's vocabulary and that many of these lessons are subsequently set out in the 2030 Agenda. Despite being revealed several centuries ago, his vision remains of great topicality, carrying the utopia of a serene and fulfilled humanity.

Some of the guidance contained in this charter includes the five thematic areas of sustainable development and more principles and means to achieve good environmental governance. 


\section{References}

[1] Ali ibn Abî Tâlib , (1989). La voie de l'éloquence. Traduction en français du texte arabe Nahj al-Balâghah par un groupe de spécialistes musulmans. Revue et corrigée par Sayyid Attia Abul Naga. Dar Al Kutub Al-Islamiyya, Dar Al Kitab- Al Lubnani, Dar Al Kitab Al Masri.

[2] Ara, F. \& Khan, M.R. (2016). Public-Private Partnership and Governance. In: Farazmand A. (ed). Global Encyclopedia of Public Administration, Public Policy, and Governance. Springer, Cham. Doi: 10.1007/978-3-319-31816-5_2012-1.

[3] Banque mondiale, (2015). Abrégé Pensée, société et comportement. Rapport sur le développement dans le monde. Washington. https://openknowledge.worldbank.org/bitstream/handle/10986/20597/WDR2015Overview-French.pdf? sequence=8\&isAllowed=y.

[4] Beisheim, M. (2015). Die Agenda 2030 Für Nachhaltige Entwicklung: Ein Ausblick Auf Ihre Weiterverfolgung Und Überprüfung. Vereinte Nationen: German Review on the United Nations, 63(6), 255-260.

[5] Braspenning Radu, O., van den Berg, M., Klimont, Z., Deetman, S., Janssens-Maenhout, G., Muntean, M., Heyes, C., Dentener, F., van Vuuren, D.P. (2016). Exploring synergies between climate and air quality policies using long-term global and regional emission scenarios. Atmospheric Environment. DOI: 10.1016/j.atmosenv.2016.05.021.

[6] Buresi, P., Bourmaud, P., Ghouirgate, M., Hitzel, F., Lefèvre, C., Madinier, R. \& Oualdi, M. (Dir) (2018). Histoire des pays d'Islam: De la conquête de Constantinople à l'âge des révolutions. Paris: Armand Colin. Doi: 10.3917/arco.hitze.2018.01.

[7] Caron, P. (2020). Nourrir 10 milliards d'êtres humains et assurer leur sécurité alimentaire : une question dépassée ? Raison présente, 21 (1), 11-20. Doi : 10.3917/rpre.213.0011.

[8] Chitonge H., Mokoena A., Kongo M. (2020). Water and Sanitation Inequality in Africa: Challenges for SDG 6. In: Ramutsindela M., Mickler D. (eds) Africa and the Sustainable Development Goals. Sustainable Development Goals Series. Springer, Cham. Doi : 10.1007/9783-030-14857-7_20

[9] Convention européenne des droits de l'homme (CEDH) (1950). Convention de sauvegarde des droits de l'homme et des libertés fondamentales. Rome, 4.XI. Cour européenne des droits de l'homme Conseil de l'Europe F-67075 Strasbourg cedex. https://www.cndp.ma/images/lois/Convention-europeenne-droits-homme-FRA.pdf

[10] Columbia Center on Sustainable Investment (CCSI), UNDP, UN Sustainable Development Solutions Network (SDSN) \& World Economic Forum. (2016). Mapping Mining to the Sustainable Development Goals: An Atlas. Report. Sustainable Development Solutions Network 3335. www.jstor.org/stable/resrep15880.11

[11] Châtaigner, J-M. \& Caron P. (2017). Un défi Pour la Planète : Les Objectifs de Développement Durable en Débat. IRD. Quae. ProQuest Ebook Central.

[12] Dhaoui, I. (2019). Good governance for sustainable development. MPRA Paper 92544. University Library of Munich.Germany.

[13] Dzebo, A., Brandi, C., Janetschek, H. \& lacobuta, G. (2019). Connections between the Paris Agreement and the 2030 Agenda. The case for policy coherence. Working Paper. http://comunidadpnacc.com/connections-between-the-paris-agreement-and-the-2030-agenda/

[14] Dobrescu, E-M. (2017). Agenda 2030 New perspectives. Journal of Defense Resources Management , 8(1), $165-180$.

[15] Domas-Descos, A. (2012). Exercice du droit de chasse et droit de propriété. Économie rurale, 327-328(1), 114-125.

[16] Dückers, D. (2017). Die Agenda 2030: Weniger Als Das Nötigste. German Institute of Global and Area Studies (GIGA). Doi:10.2307/resrep21169.

[17] Fankhauser, S., Sehlleier, F. \& Stern, N. (2008). Climate change, innovation and jobs. Climate Policy, 8(4), 421-429. Doi: $10.3763 /$ cpol.2008.0513

[18] FAO, FIDA, OMS, PAM \& UNICEF. (2017). L'État de la sécurité alimentaire et de la nutrition dans le monde : Renforcer la résilience pour favoriser la paix et la sécurité alimentaire. Rome. FAO.

[19] Gardner, T.A. Benzie, M., Börner, J., Dawkins, E., Fick, S., Garrett, R., Godar, J., Grimard, A., Lake, S., Larsen, R.K., Mardas, N., McDermott, C.L., Meyfroidt, P., Osbeck, M. \& Persson, M. (2019). Transparency and sustainability in global commodity supply chains. World Development, Elsevier, 121(C), 163-177.

DOI: 10.1016/j.worlddev.2018.05.025

[20] Gilpin, R. (2016). The political economy of international relations. Princeton University Press.

[21] Heal, G. \& Ayong Le Kama, A. (2011). Durabilité, croissance et prospérité. Revue Française D’économie, XXVI(2), 95-114. Doi : $10.3917 /$ rfe.112.0095

[22] Hossen Z. \& Khondker, B.H. (2020). How Is India Flaring in Achieving SDG 10 on Reduced Inequality?. In: Hazra S., Bhukta A. (eds) Sustainable Development Goals. Sustainable Development Goals Series. Springer. Cham. Doi :10.1007/978-3-030-42488-6

[23] Hueskes, M., Verhoest, K. \& Block, T. (2017). Governing public-private partnerships for sustainability: An analysis of procurement and governance practices of PPP infrastructure projects Governing public-private partnerships for sustainability. International Journal of Project Management, 35(6), 1184-1195.

[24] Hyden, G. (2001). Operationalizing governance for sustainable development, Journal of Development Societies, 17(2), 13-31. doi: $10.1163 / 156914901753386949$.

[25] Irdas, A., (2018). 10 Assassinats emblématiques de l'histoire de l'islam, Editions Almaarri

[26] Juknevciene V. \& Krateivaite R. (2012). Good governance as the instrument for the implementation of sustainable development's conception. Social Research, 3 (28),28- 42.

[27] Janowski, T. Estevez, E. \& Baguma, R. (2018). Platform governance for sustainable development: Reshaping citizen administration relationships in the digital age. Government Information Quarterly, 35(4), 1-16. Doi: 10.1016/j.giq.2018.09.002.

[28] Kemp, R., Parto, S. \& Gibson, R.B. (2005). Governance for sustainable development: moving from theory to practice. Int. J. Sustainable Development, $8,(1 / 2), 12-30$. 
[29] Kerras, H., Sánchez, J- L., López, E. \& Gómez, M. (2020). The impact of Gender Digital Divide on Sustainable Development: Comparative Analysis between the European Union and the Maghreb. Sustainability. MDPI. Open Access Journal, 12(8), 1-30. Doi:10.3390/su12083347

[30] Lemos, M., Agrawal, A. (2006). Environmental governance. Annual Review of Environmental Ressources, 31, $297-325$. Doi:10.1146/annurev.energy.31.042605.135621.

[31] Lennan, A- M. Ngoma, W- Y. (2004). Quality governance for sustainable development? Progress in Development Studies, 4(4), 279293. Doi : 10.1191/1464993404ps0910a

[32] Lequette, Y., Terré F., Capitant, H. (2007). Les grands arrêts de la jurisprudence civile. 12e édition, Dalloz.

[33] Linders, D. (2012). From e-government to we-government: Defining a typology for citizen coproduction in the age of social media. Government Information Quarterly, 29(4), 446-454 Doi: 10.1016/j.giq.2012.06.003.

[34] Marx, A. (2019). Public-Private Partnerships for Sustainable Development: Exploring Their Design and Its Impact on Effectiveness. Sustainability, 11(4), 1-9. Doi:10.3390/su11041087

[35] Meadows D., Meadows D. L., Randers J. \& Behrens W. W. (1972). Halte à la croissance? Rapport sur les limites de la croissance. Rapport au Club de Rome.

[36] McMichael, P. (2016). Development and social change: A global perspective. Sage Publications.

[37] McCollum, D. L., Zhou, W., Bertram, C., de Boer, H.-S., Bosetti, V., Busch, S., ... Riahi, K. (2018). Energy investment needs for fulfilling the Paris Agreement and achieving the Sustainable Development Goals. Nature Energy, 3(7), p. 589-599. DOI: 10.1038/s41560-018-0179-z. [38] Meuleman, L. (2019). Metagovernance for Sustainability - A framework for implementing the Sustainable Development Goals. (Vol. Milton Park). London. Routledge.

[39] Meadowcroft, J. (2007). Who is in Charge here? Governance for Sustainable Development in a Complex World. Journal of Environmental Policy \& Planning, 9(3-4), 299-314. DOI: 10.1080/15239080701631544.

[40] Munslow, B. (2003). Complex emergencies and development. Seminar Paper presented at the University of the Witwatersrand. South Africa.

[41] Nakshawani, S-A. (2012). The Fourteen Infallibles: A Compilation of Speeches and Lectures. Sun Behind the Cloud Publications.

[42] Nations Unies, (2002). Rapport du Sommet mondial pour le développement durable. Johannesburg (Afrique du Sud). https://undocs.org/pdf?symbol=fr/A/CONF.199/20.

[43] Nations Unies (ONU), (2002). Créer des opportunités pour les générations futures", Rapport arabe sur le développement humain. New York.

[44] Nations Unies, (ONU), (2012). Déclaration de la réunion de haut niveau de l'Assemblée générale sur l'état de droit aux niveaux national et international. A/RES/67/1. https://undocs.org/fr/A/RES/67/1

[45] Nations Unies (ONU), (2015). Transformer notre monde : le Programme de développement durable à l'horizon 2030. Documents officiels de l'Assemblée générale, Soixante et onzième session, Résolution A/RES/70/1. Par. 35

[46] Nations Unies (ONU), (2016). Rapport sur les objectifs de développement durable. New York.

[47] Nation Unies (ONU), (2017). Travaux de la Commission de statistique sur le Programme de développement durable à l'horizon 2030, Documents officiels de l'Assemblée générale, Soixante et onzième session, A/RES/71/313.

[48] OECD, (2018). Policy Coherence for Sustainable Development. Towards Sustainable and Resilient Societies. Paris: OECD.

[49] Paoletto, G. (2000). Public-private sector partnerships: an overview of cause and effect. In: Wang, Y. (ed). Public-private partnerships in the social sector: issues and country experiences in Asia and the Pacific. Asian Development Bank Institute. Tokyo, 30-47

[50] Programme des Nations Unies pour le développement (PNUD), 2002. Rapport arabe sur le développement humain 2002. New York. Publications des Nations Unies.

[51] Shah-Kazemi, R. (2006). A Sacred Conception of Justice in Imam 'Alī's Letter to Mālikal-Ashtar. In: Justice and Remembrance: Introducing the Spirituality of Imam' Ali. London: I.B.Tauris, 73-133.

[52] Rockström, J., Steffen, W., Noone, K., Persson, Å., Chapin III, F. S., Lambin, E. F., ... \& Nykvist, B. (2009). A safe operating space for humanity. Nature, 461(7263), 472-475. Doi: 10.1038/461472a.

[53] Temmer, J. \& Wiebe, K. (2018). Tracking the SDGs in Canadian Cities: SDG 8. International Institute for Sustainable Development (IISD). www.jstor.org/stable/resrep14766.

[54] Tosun, J., \& Leininger, J. (2017). Governing the interlinkages between the sustainable development goals: Approaches to attain policy integration. Global Challenges, 1(9), 1-12

[55] United Nations General Assembly (UNGA), (2015). Transforming our World: The Agenda 2030 for Sustainable Development. A/RES/70/L.1.

[56] Vaidya H. \& Chatterji T. (2020). SDG 11 Sustainable Cities and Communities. In: Franco I., Chatterji T., Derbyshire E. \& Tracey J. (eds). Actioning the Global Goals for Local Impact. Science for Sustainable Societies. Springer, Singapore.

[57] Wölkner, S. (2019). Agenda 2030: Mut Zur Nachhaltigkeit! Konrad Adenauer Stiftung. :www.jstor.org/stable/resrep19768.

[58] WCED, (1987). Our Common Future. World Commission on Environment and Development, Oxford University Press. 